\title{
Strategic Corporate Social Responsibility and Value Creation: Empirical Study in Palestine
}

\author{
Randa Sleibi ${ }^{1} \&$ Naser Abdelkarim ${ }^{2}$ \\ ${ }^{1}$ Research Assistant, Arab American University, Palestine \\ 2 Assistant Professor, Graduate School of Business and Finance, Arab American University, Palestine \\ Correspondence: Naser Abdelkarim, Assistant Professor, Graduate School of Business and Finance, Arab American \\ University, Palestine.
}

Received: April 26, 2021

Accepted: May 26, 2021

Online Published: July 28, 2021

doi:10.5430/rwe.v12n4p25

URL: https://doi.org/10.5430/rwe.v12n4p25

\begin{abstract}
This study empirically evaluates the potential relation between strategic Corporate Social Responsibility (CSR) dimensions and strategic value creation and establishes an order of importance of these dimensions according to Palestinian public shareholding corporates listed on Palestine Exchange. This is a quantitative research that analyzes corporates' responses on a descriptive and correlational questionnaire designed specifically for the research purpose.

Cross-sectional analysis revealed important correlations between the strategic value and CSR dimensions across various sectors, such as a strong positive correlation with Proactivity in the Banking sector, a moderate negative correlation with Voluntarism in the Industrial sector, a strong positive correlation with Visibility in the Investment and Services sectors and no correlation in the Insurance sector. The order of preference with respect to dimensions also varied among sectors: the most important dimensions for the Banking, Industrial, Investment, Services and Insurance sectors were Visibility, Centrality, Voluntarism, Centrality and Proactivity; Respectively.
\end{abstract}

Keywords: corporate social responsibility, value creation, Palestine, strategic dimensions, competitive advantage, strategic management

\section{Introduction}

The term Corporate Social Responsibility (hereinafter, CSR) was initially introduced in the fifties of the last century and has evolved tremendously since then. In fact, CSR proved to be a dynamic concept which operates within the realms of an ever-changing world. Currently, the focus is oriented towards incorporating CSR in the core of the businesses and using it as a strategic tool that benefits the community and simultaneously creates an added value for the firm itself.

At its very best, CSR should be used by businesses as an effective tool to "...contribute to sustainable economic development by working with employees, their families, the local community, and society at large to improve quality of life in ways that are both good for business and good for development" (World Bank, 1999). This is easier said than done and the impetus for sustainable development through CSR has to start organically at the very top. Essentially, we are reliant on businesses having a real sense of social responsibility towards their communities. This means striking a balance between maximizing profits and respecting human rights, having good governance, promoting health and safety, taking care of the environment, and contributing to economic development.

Researchers agree that a well-planned CSR strategy can be a source of opportunities and competitive advantages for its ability to create a private value for the company while creating a public value for the society. Of course, CSR should be weaved into the strategic fabric of the businesses in a customized way that best suits their contexts and competencies. However, regardless of their differences, there are several features whose presence in any CSR strategy would magnify its impact: Centrality, Specificity, Proactivity, Voluntarism and Visibility.

In this case, there appears to be no study previously conducted on CSR integration and implementation within Palestinian companies to determine whether CSR is viewed as a strategic component of the business or a mere accessory to it. It is important to remark that judging entities as socially responsible or irresponsible is not an easy task. It gets complicated because the CSR performance in the same business varies among different areas. For example, is a business that is so generous in charity initiatives called responsible, even if it pays its employees low wages with 
minimal benefits? And what if it is fair to the employees, generous to the society, but harmful to the environment? Is it considered socially responsible? Therefore, the aim of this research is not to evaluate corporates in terms of CSR, but to evaluate their CSR programs; are they strategically planned? Is there a relation between the strategic features of CSR and value creation in the Palestinian context? And which dimensions are prioritized among the sectors?

\subsection{Problem Statement}

An effective CSR strategy is a source for opportunities and competitive advantages, for it has the potential to create private value for the shareholders while creating public value for the society. To the best of the author's knowledge, no research was previously done on a Palestinian level to assess CSR as a strategic tool or to evaluate the relation between the strategic dimensions of CSR and the added value potentially created by well incorporated CSR strategies.

The purpose of this study is to evaluate the strategic dimensions of CSR programs in Palestine and their potential relation with value creation, using the Burke and Logsdon (1996) framework. Moreover, this study will determine which dimensions are recognized as essential towards creating value and thereby establish an order of importance as perceived by Palestinian corporates. This is a pioneer study that examines strategic CSR in a Palestinian context revealing the path towards better strategic management of responsibility which can be achieved by understanding how CSR dimensions correlate with value creation. As far as can be ascertained, it is the first territorial study that evaluates CSR programs and correlates their strategic dimensions with value creation.

\subsection{Research Questions}

1. What is the relation between the strategic dimensions of CSR and value creation?

2. What is the order of importance of the strategic CSR dimensions in the Palestinian corporates?

\section{Literature Review}

\subsection{Definition \& History}

A large number of scholars have been reflecting on the definitions and dimensions of Corporate Social Responsibility. As a concept, CSR has been elusive to pin down into a widely accepted definition because there are several definitions for CSR. On one hand, CSR is constantly evolving and changing to meet the demands of the various interests represented, whether it is the community, the government or the business entities. It -therefore- acquired different meanings and combined features and characteristics over time (Moon, 2002). On the other hand, many of the definitions have divergent focal points (Hamidu et al., 2015) that are not explained by the time factor. CSR is actually relative, context dependent and can be seen as an umbrella concept that varies with the time and place. A starting point would be to overview different schools of thought about CSR.

Howard Bowen - father of term social responsibility- was the first to ask and consider "what responsibilities to society may businessmen reasonably be expected to assume?' He recognized that businesses were crucial "centers of power" and their actions could touch millions of lives. He defined CSR as the set of moral and personal obligations that the employer must follow, considering the exercise of policies, decisions or courses of action in terms of objectives and values desired by society' (Bowen, 1953).

Since then, CSR has gone through several iterations comprised of different meanings. CSR was defined as 'decisions and actions taken for reasons at least partially beyond the firm's direct economic or technical interest' (Davis, 1960), as 'a commitment of business to contribute to sustainable economic development, working with employees, their families, the local community and society at large to improve the quality of life in ways that are both good for business and good for development'(World Business Council for Sustainable Development WBCSD, 1999), or as 'the overall contribution of business to sustainable development' (Ward \& Wilson, 2007). CSR was also defined as operating in an ethical way which exceeds statutory requirements (Sriramesh et al., 2007), sacrificing profits in the social interest (Bénabou and Tirole, 2009), or treating the firm's stakeholders responsibly (Abd Rahim et al., 2011). For the purpose of this research, the definition of the Palestinian Central Bureau of Statistics (PCBS) will be applied, which is: "the social responsibility is a culture that reflects commitment of a corporation towards society as part of its strategic planning to support economic, social and environmental sustainable development."

(Dahlsrud, 2008) said that the abundance of CSR definitions is preventing the development and implementation of the concept. In fact, the numerous heterogeneous definitions are confusing and are leading CSR as a concept to be used by different people to mean different things. In an attempt to find the similarities and differences between CSR definitions, he gathered and studied thirty seven existing definitions, categorized the main frequently used aspects and consequently concluded five main dimensions relating to CSR: stakeholder, social, economic, voluntariness, and an environmental dimension. 
In their analysis, Hamidu et al. (2015) researched the definitions of CSR which have emerged since the 1950's up until the $21^{\text {st }}$ century and were able to summarize each period's focus areas highlighting that the main focus during the 1950's - 1960's was philanthropy; such as religious and humane philosophies, community development and an obligation to the society...etc. Moving on to the 1970's - 1980's, the focus shifted to regulated CSR, such as extension of CSR commitments, symbol of corporate citizenship, stakeholders' rights...etc. Later in the 1990's up to this day, the attention is on instrumental/ strategic CSR. In fact, the emphasis on regulating CSR is easily noticeable especially over the last 10 years; it is no longer seen as a voluntary approach that businesses can choose to perform, but a regulated instrument that businesses should incorporate into their strategies.

As one can gather from the preceding paragraphs, the term CSR has evolved tremendously over the years since it was initially introduced by Bowen (1953). In fact, the field of CSR has obtained several theories and approaches, with the original problem holding true: same terminologies having different meanings (Garriga \& Melé, 2004). Even Carroll: one of the most influential scholars in this field has described CSR as an "eclectic", "broad", "loose" and a "multidisciplinary" field. Accordingly, he built a visual model to invoke a better understanding of CSR, expound upon in the following section.

\subsection{Pyramid of Responsibilities}

In his widely accepted model called the pyramid of responsibilities, (Carroll, 1979) defined four different yet interrelated responsibilities: Economical, legal, ethical and philanthropic.

\subsubsection{Economic Responsibility}

The basic logic of businesses is to provide goods and services in return for profit. In fact, the incentive was always profit and has recently transformed into maximizing profits, proved by maximizing earnings per share for the stockholders of the business.

Although being profitable is fundamental for the businesses' existence that it may seem uncommon to look at it as an integral part of CSR, still, it comes at the base of the pyramid. The keyword here is profit; while profit is the main goal of any business, in aiming to make profits, businesses are producing goods and providing services that are adding value and benefiting the community. Conversely, the more profitable a business is, the more likely their owners are to reinvest this profit back into the business, leading not only to higher growth, but further value to the surrounding community.

\subsubsection{Legal Responsibility}

The laws and regulations of the state and the local governments are the ground rules that should be respected while businesses pursue their economic goals. In fact, businesses are required to obey the laws and regulations set by the government and are expected to be consistent with the rules of the country in which they operate. Moreover, they should be law-abiding corporate citizens and ought to meet the minimal legal requirements of goods and services. All this falls as part of their inevitable yet unsigned "social contract".

\subsubsection{Ethical Responsibility}

It is essential for businesses to go beyond respecting legal restrictions; they are expected to be exemplary citizens by being consistent with the societal ethics and moral norms even the ones not codified into law. In fact, business performance should not merely be compliant with laws and regulations, it should recognize societal mores and ethical norms and not to compromise them for the sake of increased profit. In addition, businesses are expected to meet higher standards than the ones required under law keeping in mind what the greater society -employees, customers, shareholders...etc. - regard as just and fair.

\subsubsection{Philanthropic Responsibility}

This element includes the actions that businesses voluntarily undertake to promote the wellbeing of the community; demanding businesses to sacrifice resources for the benefit of the society.

The business with a strong CSR should make profit, follow the laws and regulations, behave ethically and be a good corporate citizen. In fact, businesses are required to be economically and legally responsible and are expected to be ethically responsible. The cherry on the top is that extra step that businesses are not required, neither expected, but desired to undertake. And this is where Strategic CSR manifests itself; in the philanthropic activities that are completely voluntary, incur costs, have risks and benefits and therefore affect the business' success or failure.

From the surface, it may seem that there is a trade-off between economic and philanthropic responsibilities since spending on the latter will sabotage the main aim of businesses: profit maximization. However, this is where things 
get interesting! There is, in fact, a win-win situation that creates private value for the shareholders while creating public value for the society (Rangan et al., 2012). And accordingly, CSR, when planned and executed in a strategic way, can become a source of opportunities and competitive advantage (Porter \& Kramer, 2006). This "shared value" can be created when CSR is incorporated in business strategies in a way that transforms the CSR spending logic from "sacrificing some profit for the public good" into "creating private value while contributing to the public good".

Nowadays, the focus is on instrumental and strategic CSR, and the worthwhile research is revolving around CSR's implementation, such as the impact of CSR on organizational performance (Martinez et al., 2016) and the methods of incorporating it into a firm's business strategies (Dahlsrud, 2008).

The abundance of literature on CSR worldwide predicts rich literature on a Palestinian level especially that in such a complicated socioeconomic situation, the private sector - through CSR- has the potential to play a key role in filling the development gap. However, this is not the case: CSR in Palestine is under-researched. For example, the first -and onlysurvey done by PCBS was in 2009, with 12 years old insights that no longer apply to the status of CSR nowadays. In addition, even the concept has been there since the 1950's, the Palestinians started researching it only in the 2000's by notably a few researchers, whose studies focused on the status of CSR in the Palestinian context such as the businesses' awareness of CSR, the intentions for CSR spending...etc. without addressing strategic CSR, its implementation, its effect on the businesses or on the economy.

This study is the first to investigate strategic CSR in the Palestinian context, using Buke and Logsdon framework (1996) which operationalizes five strategic dimensions necessary to magnify the impact of CSR programs on the organizational performance and consequently create strategic value: Centrality, Specificity, Proactivity, Voluntarism and Visibility. Their model is thoroughly explained in the following section.

\section{Theoretical Framework}

The strategic approach of CSR activities that would enable CSR spending to create shared value was established by Burke and Logsdon (1996). The five-dimension strategy they introduced presents the key to creating a shared value out of CSR: The reorientation of CSR towards a more strategic scheme by reforming the CSR activities.

Burke and Logsdon (1996)'s model is an instrument that can be used in designing and evaluating CSR strategies. For its significance, it has been empirically tested by several scholars in different contexts and has been cited extensively by researchers in the field of CSR. Their model enables an assessment of CSR activities and their impact on strategic value.

In their model, Burke and Logsdon (1996) developed five strategic dimensions that are needed for CSR to be strategic and create shared value. These dimensions can be seen as features of CSR activities that -when present- create a value for the business while creating value for its stakeholders.

\subsection{CSR Strategic Dimensions}

Centrality is "a measure of the closeness of fit between a CSR policy or programme and the firm's mission and objectives" (Burke and Logsdon, 1996). CSR is therefore more strategic when its' programs are not isolated from the business' mission, but strongly linked to it. In fact, the closer the relation between the CSR programs and the business' core mission, the higher the business value created.

Specificity determines "the extent in which the company captures or internalizes the benefits from its CSR activities for itself, minimizing the capacity of other organizations to take advantage of such benefits" (Camarena-Martinez \& Wendlandt-Amezaga, 2017). The main point of the specificity dimension is to ensure that the added business value attained from CSR is not shared with others in the industry or the community, but is directly attributed to the firm itself.

Proactivity reflects "the degree to which behavior is planned in anticipation of emerging economic, technological, social or political trends and in the absence of crisis conditions" (Sun and $\mathrm{Li}, 2017$ ). In fact, proactively planned CSR is more likely to generate value than reactive CSR, for its preference in effectively engaging stakeholders and keeping up to their expectations. Moreover, being proactive indicates a higher level of innovation, which is positively perceived by stakeholders.

Voluntarism requires that "firm social activities be undertaken freely, rather than in response to legal constraints, fiscal incentives, or industry practice" (Husted and Allen, 2009). CSR should be a discretionary plan coming from the business' conviction, good governance and self-motivation, without external requirements that the business is complying to. 
Visibility denotes "both the observability of a business activity and the firm's ability to gain recognition from internal and external stakeholders" (Sun and Li, 2017). This makes perfect sense since visibility directly affects the reputation, image, brand differentiation and hence, more value.

\subsection{Strategic Value Creation}

Again, strategic CSR is the use of CSR to capture a win-win situation that simultaneously generates shared value for the community and for the business entity, best described by Lantos (2001): 'There is nothing morally objectionable to doing well while doing good, to help the Stockholders while aiding other stakeholders.'

While a direct influence of CSR on the performance of the business is disputed, a mediated relationship in which CSR plays an indirect role in the business' performance is confirmed, since it has a positive effect on competitive advantage, reputation and customer satisfaction, which highly affect the performance (Saeidi et al., 2015). So, even though directly connecting CSR to changes in business performance is not easily attainable, research proves it to have a positive impact on the businesses incorporating it on several intangible aspects:

- Reputation: Evidence in the literature confirms the positive correlation between CSR and corporate reputation. A good reputation translates into a strengthened brand name and may even lead to raising the stock value (Porter \& Kramer, 2006). Moreover, a strong reputation and a responsible image save companies from negative news or propaganda (Bhattacharya \& Sen, 2004).

- Employees: a business with a socially responsible reputation is a good attractor for new recruitments and retainer for current employees. Indeed, having a social sense motivates employees (Sprinkle \& Maines, 2010) (weber, 2008).

- Consumers: Consumers are influenced by socially responsible initiatives. In fact, CSR connects companies with consumers (Polonsky \& Jevons, 2009). For example, some consumers prefer purchasing from and associating with companies with a remarkable sense of social responsibility over other competing companies (Kim et al. 2014). In addition, it is argued that consumers' criteria towards products are recently evolving to include more than the traditional features such as price and quality; CSR product features are now considered in the buying process (Feldman \& Vasquez-Parraga, 2013).

- Financial Performance: The above-mentioned benefits inevitably translate into higher revenue due to higher sales and market share (Weber, 2008) which contributes in levering the market value of stocks. In addition, surveys have shown that those who engage in CSR activities which are mostly interconnected with the overall strategy and business model of the business usually generate the highest rates of return with respect to a positive return on investment. Several researchers have endorsed the positive effect of CSR on Corporate Financial Performance (CFP). For example, Wang et al. (2016) quantitatively studied the link between CSR and CFP and assured the significance of the positive link between them. Moreover, Frooman (1997) stated that ignoring CSR can harm shareholders' wealth. Thus, maintaining a strong CSR will eventually pay off for the company in terms of financial performance.

There is a legitimate concern that questions the motivations for CSR. Many businesses are aware of the benefits of CSR that they use it as "window dressing": a plain public relations tool that magnifies the exploitation more than the actual initiative. Rangan et al. (2012) confirms this saying “... corporate programs to fund social and environmental programs are nothing more than public relations campaigns to boost their brand reputations, often disproportionately to the effort itself." It is also noted that CSR is commonly treated as a cosmetic response that shows off the businesses' good deeds using glossy CSR initiatives (Porter \& Kramer, 2006).

The intrinsic intention for CSR depends on the management itself. In his research, Carroll (1991) discussed three types of managements: Moral, Amoral and Immoral. Obviously, immoral is the complete opposite of moral and amoral comes somewhere in between: While immoral managers only care about their companies' profitability regardless of what is ethical, moral managers respect ethical principles and behave above the minimum legal mandates and amoral ones behave according to the letter of the law, without any ethical perception. In today's business environment, incorporating CSR in strategies is vital for all kinds of managements regardless of their intentions; even immoral managements who historically criticized and ignored CSR because they perceived it as an additional unnecessary cost that hinders profit maximization, are nowadays using it strategically to increase profit and maximize wealth.

Whether it is ethical to use ethics as a strategy and the true motivation behind CSR is out of the scope of this study. In any case, it is inevitable that the orientation of CSR has extended "beyond philanthropy to instrumentality" (Hamidu et al., 2015) and the introduction of CSR as a strategy has become necessary for the business to survive and prosper (Galan, 2006). In fact, what initially started as a philanthropy act in which the business ethically bound itself to moral behaviors and generous donations for the wellbeing of the society evolved over the years to become an 
important tool that the businesses should incorporate in their strategies! CSR is indeed a strategic issue (Hancock, 2015).

\section{Methodology}

\subsection{Research Tool}

A quantitative method was also utilized for this research's purpose. A descriptive and correlational instrument was designed based on Camarena-Martinez \& Wendlandt-Amezaga (2017)'s elaboration from previous scholars' contributions. However, some modifications and additions were applied to adapt it to the Palestinian context.

The questionnaire consisted of several sections: The first section collected general background information that would be used as control variables to draw the context for the participating corporates, such as their size, age, profitability and experience in CSR. This makes perfect sense, since it is logical to connect these variables to strategic CSR. For example, corporates with higher profit tend to invest more in CSR activities. Subsequently, it was followed by a section about CSR knowledge and intention.

After the first two general sections, five sections were dedicated to assessing the constructs of Centrality, Specificity, Proactivity, Voluntarism and Visibility. Centrality was evaluated by determining the extent of relation between social goals -such as protecting the environment and supporting social causes- and the goals of the company. Specificity was assessed by verifying whether companies link their CSR to their sector and design it in a hard-to-imitate way in order to benefit from it alone. Proactivity was measured by reviewing the extent to which companies stay updated with legal changes, plan CSR ahead of time and have CSR implementation plans...etc. Voluntarism was appraised by asking about corporates' intentions for CSR and the reasons behind it: legal constraints, imitating the competitors, TAX incentives...etc. Finally, Visibility was examined by determining the level of disclosing, reporting and sharing CSR programs.

The final section -then- focused on the dependent variable: The Strategic Value derived from CSR as perceived by responding corporates, such as opening new markets, attracting new customers and developing new products and services.

A Likert scale was used ranging from 1 to 5: (1. Never / Strongly Disagree, 2. Rarely / Disagree 3. Sometimes / Neutral 4. Frequently / Agree 5. Always / Strongly Agree) allowing participants to assign a value for strategic dimensions and enabling the researcher to link between them and value creation.

The questionnaire was developed in Arabic; the mother tongue of the researcher and the target corporates. Upon the approval of the tool, it was made available in two forms: online: embedded on google, and offline: as a word document. The corporates were accordingly given the choice to fill it out as they prefer; either traditionally or using google forms.

\subsection{Sample Description}

This research targets the Palestinian public sharing companies listed on Palestine Exchange (PEX). The total number of these corporates is 46 distributed across five main sectors: Banking, Industry, Insurance, Investment and Service. Given the small size of the target group, no sampling was done and all of the corporates were included in the research.

A thorough review for the corporates' annual reports published on PEX was done prior to conducting the quantitative analysis in order to get a general description of the status of CSR among them. The quality of CSR reporting varied among the corporates and ranged from non-existent to detailed. Some corporates had no hint of CSR in their annual reports (three corporates) (Note 1), others clearly stated that they do not have CSR (four corporates) (Note 2) and some of them had no financial reporting of CSR along with very brief narrative reporting (eight corporates) (Note 3). As a result, these fifteen corporates were excluded from further analysis. Consequently, thirty-one corporates were approached with the questionnaires, of which twenty-seven responded, with a response rate of eighty seven percent $(87 \%)$.

\subsection{Validity and Reliability}

The questionnaire's validity was verified by a face validity approach. The instrument was proven to have a proper structure and its questions were considered successful indicators of the variables. Therefore, it is proven to be valid.

To test the reliability of the questionnaire, its internal consistency was objectively measured using "Cronbach's alpha" with an acceptability threshold of Cronbach's Alpha $\alpha=0.7$ or above.

In fact, the reliability was tested for each section of the questionnaire independently and then for the questionnaire as a whole. The reliability of the questionnaire as a whole was measured revealing a high Cronbach's Alpha of more 
than 0.9 which attests the reliability of the instrument. However, the section of "Specificity" was considered unreliable with a Cronbach's Alpha of 0.587 and was consequently discarded from further analysis.

\section{Findings}

Twenty Seven corporates answered the questionnaire, with a response rate of $87 \%$. Respondents belonged to the Banking, Industrial, Investment $(\mathrm{N}=7,26 \%$ each), Service $(\mathrm{N}=4,15 \%)$ and Insurance $(\mathrm{N}=2,7 \%)$ sectors.

Abstract variables of the dimensions of strategic CSR and the Strategic Value were computed by calculating the median of the variables in each section of the questionnaire. The variables are: Centrality $(\mathrm{M}=3.9259, \mathrm{SD}=0.95780)$, Proactivity $(\mathrm{M}=3.4815, \mathrm{SD}=1.08735)$, Voluntarism $(\mathrm{M}=3.9259, \mathrm{SD}=1.10683)$, Visibility $(\mathrm{M}=3.2593, \mathrm{SD}=$ 1.21188) and Strategic Value ( $\mathrm{M}=2.8519, \mathrm{SD}=1.29210)$. (Note 4) All of them had the minimum value of 1 , the maximum value of 5 and consequently the range of 4 . The normality of variables was tested using Shapiro-Wilk test for it is known to be better suited for small samples than kolmogorov-Smirnov test. The normality results showed that all variables (expect for visibility) failed the normality test and violated the parametric tests' assumptions. Therefore, non-parametric tests were used in the analysis.

To answer the first research question concerning the relation between the strategic dimensions of CSR and Strategic Value creation, Spearman Rank Correlation (Note 5) was used to find the strength of the monotonic association of the dependent and independent variables.

Table 1. Correlations between the strategic dimensions of CSR and value creation

Correlations

\begin{tabular}{llccccc}
\hline \multirow{5}{*}{ Visibility } & & Visibility & Voluntarism & Proactivity & Centrality & \multicolumn{2}{c}{ Strategic_Value } \\
& Correlation Coefficient & 1.000 & -.027 & $.776^{* *}$ & .371 & .255 \\
\cline { 2 - 7 } Voluntarism & Sig. (2-tailed) &. & .893 & .000 & .057 & .198 \\
\cline { 2 - 7 } & $\mathrm{N}$ & 27 & 27 & 27 & 27 & 27 \\
\cline { 2 - 7 } & Correlation Coefficient & -.027 & 1.000 & -.001 & .195 & $1-.280$ \\
\cline { 2 - 7 } Proactivity & Sig. (2-tailed) & .893 &. & .995 & .330 & .157 \\
\cline { 2 - 7 } & $\mathrm{N}$ & 27 & 27 & 27 & 27 & 27 \\
\cline { 2 - 7 } & Correlation Coefficient & $.776^{* *}$ & -.001 & 1.000 & $.475^{*}$ & .213 \\
\cline { 2 - 7 } Centrality & Sig. (2-tailed) & .000 & .995 &. & .012 & .286 \\
\cline { 2 - 7 } & $\mathrm{N}$ & 27 & 27 & 27 & 27 & 27 \\
\cline { 2 - 7 } & Correlation Coefficient & .371 & .195 & $.475^{*}$ & 1.000 & .070 \\
\cline { 2 - 7 } Strategic_Value & Sig. (2-tailed) & .057 & .330 & .012 &. & .728 \\
\cline { 2 - 7 } & $\mathrm{N}$ & 27 & 27 & 27 & 27 & 27 \\
\cline { 2 - 7 } & Correlation Coefficient & .255 &. .280 & .213 & .070 & 1.000 \\
\cline { 2 - 7 } & Sig. (2-tailed) & .198 & .157 & .286 & .728 & 27 \\
\cline { 2 - 7 } & $\mathrm{N}$ & 27 & 27 & 27 & 27 \\
\hline
\end{tabular}

Testing the Research Hypothesis (Note 6):

- H0: The Centrality of CSR programs is related with their contribution to value creation.

Spearman Correlation Coefficient indicates a weak correlation between Centrality and Strategic Value (Rho=0.07). So, the null hypothesis is rejected and with a confidence interval of $95 \%$, it is stated that there is no significant correlation between Centrality and Strategic Value.

- H0: The Specificity of CSR programs is related with their contribution to value creation. 
This hypothesis could not be assessed, because the reliability of the variable was not accepted (Cronbach's Alpha was less than 0.7).

- H0: The Proactivity of CSR programs is related with their contribution to value creation.

Spearman correlation was run to determine if this hypothesis is true or should otherwise be rejected. The coefficient $(\mathrm{Rho}=0.213)$ determined an existing yet weak correlation between Proactivity and Strategic Value.

- H0: The Voluntarism of CSR programs is related with their contribution to value creation.

For this hypothesis, Spearman Correlation Coefficient is -0.280 , which signifies a weak negative association between Voluntarism and Value Creation. That is, when the level of Voluntarism increased, the Strategic Value that was created by CSR programs decreased.

- H0: The Visibility of CSR programs is related with their contribution to value creation.

The Spearman Correlation Coefficient between Visibility and Strategic Value was Rho $=0.255$ which indicates a weak correlation between these two variables.

As explained above, when the research hypothesis was tested for the sample as a whole, no to weak correlations were found between the dependent and independent variables. To analyze it further, some cross-sectional correlation analyses were done to find the correlation between the dependent and independent variables with respect to the controlling variables: Sector, Profitability and Size.

- Cross-Sectional Correlation by Sector:

Table 2. Cross-sectional correlation analysis between the strategic dimensions of CSR and value creation by sector

\begin{tabular}{lccccc}
\hline & $\begin{array}{c}\text { Banking } \\
\text { Sector }\end{array}$ & $\begin{array}{c}\text { Industrial } \\
\text { Sector }\end{array}$ & $\begin{array}{c}\text { Investment } \\
\text { Sector }\end{array}$ & $\begin{array}{c}\text { Services } \\
\text { Sector }\end{array}$ & $\begin{array}{c}\text { Insurance } \\
\text { Sector }\end{array}$ \\
\hline $\begin{array}{l}\text { Visibility } \times \text { Strategic } \\
\text { Value }\end{array}$ & 0.099 & -0.149 & 0.746 & 0.632 & 0 \\
\hline $\begin{array}{l}\text { Voluntarism } \times \text { Strategic } \\
\text { Value }\end{array}$ & -0.547 & -0.568 & 0.065 & 0.236 & 0 \\
\hline $\begin{array}{l}\text { Proactivity } \times \text { Strategic } \\
\text { Value }\end{array}$ & 0.637 & 0.167 & -0.452 & 0.316 & 0 \\
\hline $\begin{array}{l}\text { Centrality } \times \text { Strategic } \\
\text { Value }\end{array}$ & 0.209 & 0.313 & -0.342 & 0.544 & 0 \\
\hline $\mathrm{N}$ & 7 & 7 & 7 & 4 & 2 \\
\hline
\end{tabular}

The strongest correlation in the Banking sector was between Strategic Value and Proactivity $($ Rho $=0.637)$. There is also a moderate negative correlation between Strategic Value and Voluntarism (Rho $=-0.547)$.

The strongest association in the Industrial sector was a negative moderate correlation between Strategic Value and Voluntarism $(\mathrm{Rho}=-0.568)$, which means that the more attention the industrial corporates pay for voluntarism, the less Strategic Value they would generate out of their CSR programs.

For the Investment and Services sectors, the Visibility dimension had the strongest correlation with Strategic Value with Rho $=0.746$ in the Investment sector (strong positive correlation) and Rho $=0.632$ in the Services sector (also a strong positive correlation).

The Insurance sector had no correlation whatsoever between the CSR dimensions and the Strategic Value obtained from CSR.

- Cross-Sectional Correlation by Profitability: 
Table 3. Cross-sectional correlation analysis between the strategic dimensions of CSR and value creation by profitability

\begin{tabular}{lccc}
\hline & Less than \$1M & $\$ 1 \mathrm{M}-\$ 10 \mathrm{M}$ & More Than \$10M \\
\hline Visibility $\times$ Strategic Value & 0.6 & -0.15 & 0.645 \\
\hline Voluntarism $\times$ Strategic Value & -0.323 & -0.394 & -0.323 \\
\hline Proactivity $\times$ Strategic Value & 0.137 & -0.033 & 0.645 \\
\hline Centrality $\times$ Strategic Value & -0.068 & -0.251 & 0.645 \\
\hline $\mathrm{N}$ & 10 & 12 & 5 \\
\hline
\end{tabular}

The highest correlation among the corporates who had less than one million dollars on average of net income during 2017 and 2018 was between strategic Value and Visibility with a correlation coefficient Rho $=0.60$.

Among the second group which represents the corporates of one to ten million dollars average net income, all dimensions were negatively associated with Strategic Value with a weak correlation of no more than 0.39 each.

However, the corporates with the highest profitability (more than ten million dollars) had a strong positive correlation between Strategic Value and three dimensions of CSR, namely: Visibility, Proactivity and Centrality with a spearman correlation coefficient of Rho $=0.645$ each.

- Cross-Sectional Correlations by Size:

Table 4. Cross-sectional correlation analysis between the strategic dimensions of CSR and value creation by size

\begin{tabular}{lccc}
\hline & $\begin{array}{c}\text { Less than } 100 \\
\text { employees }\end{array}$ & $100-500$ employees & More than 500 employees \\
\hline Visibility $\times$ Strategic Value & 0.453 & 0.2 & 0.32 \\
\hline Voluntarism $\times$ Strategic Value & -0.246 & -0.378 & -0.27 \\
\hline Proactivity $\times$ Strategic Value & 0.102 & 0.144 & 0.804 \\
\hline Centrality $\times$ Strategic Value & 0.171 & -0.182 & 0.366 \\
\hline $\mathrm{N}$ & 12 & 9 & 6 \\
\hline
\end{tabular}

Most of the correlations in the above table are weak (less than 0.39) except for a moderate correlation between Strategic Value and Visibility among the small corporates (less than 100 employees) with a strength of Rho $=0.453$, and a very strong correlation between Strategic Value and Proactivity with a coefficient or Rho $=0.804$ among the big corporates (more than 500 employees).

To answer the second research question concerning the order of importance of the strategic dimension in the Palestinian context, Kruskal-Wallis (K-S) test was done. In fact, K-S is the non-parametric equivalent to one way ANOVA and it was the most appropriate test to be used in order to identify statistical differences between the mean ranks of CSR dimensions across the sectors. 
Table 5. Kruskal-Wallis (K-S) Test ranks

\begin{tabular}{|c|c|c|c|}
\hline & Sector & $\mathrm{N}$ & Mean Rank \\
\hline \multirow[t]{6}{*}{ Centrality } & Banking & 7 & 16.86 \\
\hline & Industry & 7 & 12.79 \\
\hline & Investment & 7 & 11.43 \\
\hline & Services & 4 & 18.88 \\
\hline & Insurance & 2 & 7.50 \\
\hline & Total & 27 & \\
\hline \multirow[t]{6}{*}{ Proactivity } & Banking & 7 & 21.00 \\
\hline & Industry & 7 & 11.07 \\
\hline & Investment & 7 & 11.07 \\
\hline & Services & 4 & 11.88 \\
\hline & Insurance & 2 & 14.25 \\
\hline & Total & 27 & \\
\hline \multirow[t]{6}{*}{ Voluntarism } & Banking & 7 & 14.50 \\
\hline & Industry & 7 & 8.93 \\
\hline & Investment & 7 & 16.36 \\
\hline & Services & 4 & 17.75 \\
\hline & Insurance & 2 & 14.25 \\
\hline & Total & 27 & \\
\hline \multirow[t]{6}{*}{ Visibility } & Banking & 7 & 22.07 \\
\hline & Industry & 7 & 12.21 \\
\hline & Investment & 7 & 9.86 \\
\hline & Services & 4 & 10.88 \\
\hline & Insurance & 2 & 12.75 \\
\hline & Total & 27 & \\
\hline
\end{tabular}

It is observed from the figures in the above-mentioned table that the average of mean ranges is significantly higher in the Banking sector compared to the other sectors, which signifies that the Banking Sector has the most interest and attention to CSR.

As shown in the table, the corporates in the Banking sector gave preference to the Visibility and Proactivity dimensions of CSR while planning their initiatives (Visibility $M=22.07$, Proactivity $M=21$ ) more than they cared about Centrality $(M=16.86)$ and Voluntarism $(M=14.5)$. In the Industrial Sector, the order of importance was as follows: Centrality $(M=12.79)$, Visibility $(M=12.21)$, Proactivity $(M=11.07)$ and the least important was the Voluntarism dimension $(M=8.93)$ which was the most important in the Investment sector with a mean of 16.36 , followed by Centrality ( $M=11.43)$, Proactivity $(M=11.07)$ and Visibility $(M=9.86)$. Likewise, Visibility was the least important dimension for the corporates in the Services sector with a mean of 10.88 , preceded by the Centrality $(\mathrm{M}=18.88)$, Voluntarism $(M=17.75)$ and Proactivity $(M=11.88)$ dimensions. For the Insurance sector, the same level of importance was given for Proactivity and Voluntarism $(\mathrm{M}=14.25)$ followed by Visibility $(\mathrm{M}=12.75)$ and Centrality $(\mathrm{M}=7.5)$.

\section{Summary and Conclusion}

This research paper operationalized two variables: Strategic CSR and Strategic Value and assessed their relation in the Palestinian context based on Burke and Logsdon (1996) framework. This was done by operationalizing the strategic dimensions of CSR and measuring their impact on value creation as perceived by the corporates listed on PEX. 
When computing the correlation between the strategic dimensions and the strategic value for all the corporates, no to very weak correlations were found. However, when cross-sectional analysis were undertaken, strong correlation appeared between variables. For example, the Banking sector had a strong positive relation between Strategic Value and Proactivity. In addition, the Industrial sector had a negative moderate correlation between Strategic Value and Voluntarism. Moreover, the strongest association with strategic value in the Investment and Services sectors was with Visibility.

Further analysis was done to determine the order of importance of CSR dimensions among the sectors: While the Banking sector's most preferred dimension was Visibility, the Industrial and Services sectors preferred Centrality and the Investment and Insurance sectors viewed the Voluntarism dimension as the most important.

Better management for strategic responsibility can be achieved by understanding how CSR dimensions correlate with value creation. For example, the Banking and the Industrial sectors had a negative moderate correlation between strategic value and the Voluntarism dimension (Rho $=-0.547,-0.568$, respectively). Luckily for them, these sectors gave the least importance to the Voluntarism dimension ( $\mathrm{M}=14.50$ Banking, $\mathrm{M}=8.93$ Industry). However, the Investment and the Services sectors both had a strong correlation between Strategic Value and the Visibility dimension $($ Rho $=0.746$ Investment, Rho $=0.632$ Services). Unfortunately for them, they are paying the least attention for this dimension ( $M=9.86$ Investment, $M=10.88$ Services). So, if they wish to gain more Strategic Value out of their CSR, they are advised to plan their CSR programs to be more visible. That is; they should advertise about them, share them on the social media platforms, include them in their reports and on their websites...etc.

In conclusion, adequate planning for CSR is crucial to maximize the private and the public benefits expected from it. For the community, better planning for CSR will reduce the duplication of efforts in the same fields of support and will result in fairer more complementary initiatives. For the business itself, it is proved that well-incorporated CSR dimensions will result in a higher strategic value creation in terms of increasing the customer's loyalty, attracting and retaining employees and generating higher profits.

\section{References}

Abd Rahim, R., Jalaludin, F. W., \& Tajuddin, K. (2011). The Importance of Corporate Social Responsibility on Consumer Behavior in Malaysia. Asian Academy of Management Journal, 16(1), 119-139

Ahmad, T. (2019). Corporate social responsibility: a value-creation strategy to engage millennials. Strategic Direction. https://doi.org/10.1108/SD-11-2018-0232

Bénabou, R., \& Tirole, J. (2010). Individual and corporate social responsibility. Economica, 77(305), 1-19. https://doi.org/10.1111/j.1468-0335.2009.00843.x

Bhattacharya, C., \& Sen, S. (2004). Doing better at doing good: when, why and how consumers respond to corporate social initiatives. California Management Review, 47, 9-24. https://doi.org/10.2307/41166284

Bowen, H. R. (2013). Social responsibilities of the businessman. University of Iowa Press. https://doi.org/10.2307/j.ctt20q1w8f

Burke, L., \& Logsdon, J. M. (1996). How Corporate Social Responsibility Pays Off. Long Range Planning, 29(4), 495-502. https://doi.org/10.1016/0024-6301(96)00041-6

Camarena-Martinez, J. L., \& Wendlandt-Amézaga, T. R. (2017). Strategic CSR Dimensions and Value Creation in Socially Responsible Mexican Firms.

Carroll, A. B. (1979). A three-dimensional conceptual model of corporate performance. Academy of Management Review, 4(4), 497-505. https://doi.org/10.5465/amr.1979.4498296

Carroll, A. B. (1991). The pyramid of corporate social responsibility: Toward the moral management of organizational stakeholders. Business Horizons, 34(4), 39-48. https://doi.org/10.1016/0007-6813(91)90005-G

Dahlsrud, A. (2008). How Corporate Social Responsibility is defined: an Analysis of 37 Definitions. Corporate Social Responsibility and Environmental Management, 15, 1-13. https://doi.org/10.1002/csr.132

Davis, K. (1960). Can business afford to ignore social responsibilities?. California Management Review, 2(3), 70-76. https://doi.org/10.2307/41166246

Feldman, P. M., \& Vasquez-Parraga, A. Z. (2013). Consumer social responses to CSR initiatives versus corporate abilities. Journal of Consumer Marketing, 30, 100-111. https://doi.org/10.1108/07363761311304915 
Fernández-Guadaño, J., \& Sarria-Pedroza, J. H. (2018). Impact of corporate social responsibility on value creation from a stakeholder perspective. Sustainability, 10(6), 2062. https://doi.org/10.3390/su10062062

Frooman, J. (1997). Socially irresponsible and illegal behavior and shareholder wealth: A meta-analysis of event studies. Business \& Society, 36(3), 221-249. https://doi.org/10.1177/000765039703600302

Galan, J. I. (2006) Corporate social responsibility and strategic management. Journal of Management Studies, 43(7), 1629-41. https://doi.org/10.1111/j.1467-6486.2006.00655.x

Garriga, E., \& Melé, D. (2004). Corporate social responsibility theories: Mapping the territory. Journal of Business Ethics, 53(1-2), 51-71. https://doi.org/10.1023/B:BUSI.0000039399.90587.34

Hamidu, A., Haron, M., \& Amran, A. (2015). Corporate social responsibility: A review on definitions, core characteristics and theoretical perspectives. Mediterranean Journal of Social Sciences. https://doi.org/10.5901/mjss.2015.v6n4p83

Hancock, H. (2015). Corporate social responsibility \& strategy. Undergraduate Winner IBE Student Essay Competition. Pdf.

Husted, B. W., \& Allen, D. B. (2009). Strategic corporate social responsibility and value creation. Management International Review, 49(6), 781. https://doi.org/10.1007/s11575-009-0016-5

Kim, M. S., Kim, D. T., \& Kim, J. I. (2014). CSR for sustainable development: CSR beneficiary positioning and impression management motivation. Corporate Social Responsibility and Environmental Management, 21(1), 14-27. https://doi.org/10.1002/csr.1300

Lantos, G. P. (2001). The boundaries of strategic corporate social responsibility. Journal of Consumer Marketing, 18(7), 595-630. https://doi.org/10.1108/07363760110410281

Martínez, J. B., Fernández, M. L., \& Fernández, P. M. R. (2016). Corporate social responsibility: Evolution through institutional and stakeholder perspectives. European Journal of Management and Business Economics, 25(1), 8-14. https://doi.org/10.1016/j.redee.2015.11.002

Moon, J. (2002). Corporate Social Responsibility: An Overview. The International Directory of Corporate Philanthropy, 1, 14-18.

Mosca, F., \& Civera, C. (2017). The evolution of CSR: An integrated approach. Symphonya. Emerging Issues in Management, (1), 16-35. https://doi.org/10.4468/2017.1.03mosca.civera

Palestinian Central Bureau of Statistics. (2011). Social responsibility of the private sector (30 employees and above), in The Palestinian Territories. Main Findings. Ramallah Palestine.

Polonsky, M., \& Jevons, C. (2009). Global branding and strategic CSR: an overview of three types of complexity. International Marketing Review, 26, 327-347. https://doi.org/10.1108/02651330910960816

Porter, M. E., \& Kramer, M. R. (2006). The link between competitive advantage and corporate social responsibility. Harvard Business Review, 84(12), 78-92.

Rangan, K., Chase, L. A., \& Karim, S. (2012). Why every company needs a CSR strategy and how to build it.

Retrieved from www.pex.ps

Saeidi, S. P., Sofian, S., Saeidi, P., Saeidi, S. P., \&Saeidi, S. A. (2015). How does corporate social responsibility contribute to firm financial performance? The mediating role of competitive advantage, reputation, and customer satisfaction. Journal of Business Research, 68(2), 341-350. https://doi.org/10.1016/j.jbusres.2014.06.024

Sprinkle, G. B., \& Maines, L. A. (2010). The benefits and costs of corporate social responsibility. Business Horizons, 53, 445-453. https://doi.org/10.1016/j.bushor.2010.05.006

Sriramesh, K., Ng, C. W., Ting, S. T., \& Wanyin, L. (2007). Corporate social responsibility and public relations. In S. May, G. Cheney, \& J. Roper (Eds.), The Debate over Corporate Social Responsibility

Sun, L., \& Li, Y-H. (2017). Case Study on Strategic Corporate Social Responsibility of G Company. International Review of Management and Business Research, 6(4), 1349-1359.

Wang, Q., Dou, J., \& Jia, S. (2016). A meta-analytic review of corporate social responsibility and corporate financial performance: The moderating effect of contextual factors. Business \& Society, 55(8), 1083-1121. https://doi.org/10.1177/0007650315584317 
Ward, H., Wilson, E., \& Zarsky, L. (2007). CSR and Developing Countries. Sustainable Development Innovation Briefs, (1), 1-8.

Weber, M. (2008). The business case for corporate social responsibility: a company level measurement approach for CSR. European Management Journal, 26, 247-61. https://doi.org/10.1016/j.emj.2008.01.006

World Business Council for Sustainable Development. (1999). Corporate Social Responsibility: Meeting Changing Expectations. World Business Council for Sustainable Development: Geneva.

\section{Notes}

Note 1. JREI, NSC, WASSEL

Note 2. ARAB, PID, ABRAJ, RSR

Note 3. LADAEN, NCI, PHARMACARE, PICO, TIC, TRUST, AQARIYA and PALAQAR

Note 4.The Specificity variable was excluded from further analysis since its $\alpha$ was below the acceptable 0.7 and is consequently not considered reliable.

Note 5. Spearman Correlation Coefficient is: very weak $0.00-0.19$, weak 0.20-0.39, moderate 0.40-0.59, strong $0.60-0.79$ and very strong $0.80-1.00$

Note 6. The degree of correlation was described without indicating its significance since the Sig Value is dependent on the sample size which is small in this research leading the sig values to be insignificant.

\section{Copyrights}

Copyright for this article is retained by the author(s), with first publication rights granted to the journal.

This is an open-access article distributed under the terms and conditions of the Creative Commons Attribution license (http://creativecommons.org/licenses/by/4.0/). 